\title{
Seasonal and latitudinal patterns of pelagic community metabolism in surface waters of the Atlantic Ocean
}

\section{S. Agusti ${ }^{1,2}$}

${ }^{1}$ Department of Global Change Research, IMEDEA (CSIC-UIB) Instituto Mediterráneo de Estudios Avanzados, Calle Miquel Marqués 21, 07190 Esporles, Balearic Islands, Spain

${ }^{2}$ The UWA Oceans Institute and School of Plant Biology, The University of Western Australia, 35 Stirling Highway, Crawley 6009, Australia

Received: 19 November 2011 - Accepted: 22 November 2011 - Published: 16 January 2012 Correspondence to: S. Agusti (sagusti@imedea.uib-csic.es)

Published by Copernicus Publications on behalf of the European Geosciences Union.

Seasonal and latitudinal patterns of pelagic community metabolism

S. Agusti

Title Page

Abstract Introduction

Conclusions

Tables

References

Figures

14

4

Back

Close

Printer-friendly Version

Interactive Discussion 


\section{Abstract}

Temporal and spatial patterns in the variability of the pelagic metabolism at the surface of the Atlantic Ocean were analyzed in a series of four oceanographic cruises (LATITUDE 1, 2, 3 and 4). The cruises crossed the oligotrophic waters of North and South 5 subtropical gyres and this explained the low values of both gross primary production (GPP) and community respiration $(R)$ found. Net community production (NCP), the balance between production and consumption, was strongly related to the variability in $R$ rates $\left(R^{2}=0.72, P<0.0001\right)$. NCP was net heterotrophic in $83 \%$ of the data, but showed strong temporal and spatial patterns. At the inter-tropical zone, around $10^{\circ}-$ $12^{\circ} \mathrm{N}$ and $10^{\circ}-12^{\circ} \mathrm{S}$, a large variability was observed with values of NCP oscillating from net heterotrophic to net autotrophic seasonally. This variability implied NCP to be net autotrophic in boreal fall and austral spring, and net heterotrophic in boreal spring and austral fall, in the areas around the boundaries of the inter-tropical zone. The variability observed concur with the seasonal climatic and oceanographic regimes of the inter-tropical area, whith documented seasonal changes of the North and South Atlantic equatorial currents system, the Guinea Dome, and the Benguela current. When considering the season of the data obtained, significant differences between spring and fall were found for the surface Atlantic, with water temperature and respiration increasing in autumn, showing a net heterotrophic metabolism, and with temperature and respiration decreasing in spring, where NCP were closer to the metabolic balance. In contrast, no seasonal differences were found for GPP and chlorophyll-a concentration. The results showed new spatial and temporal patterns in the pelagic metabolic balance of the surface Atlantic Ocean with consequences for the carbon flux.

\section{Introduction}

25 The importance of oceanic biota in the net absorption of atmospheric $\mathrm{CO}_{2}$ depends on the net community production, i.e. on the balance between the carbon fixed by primary
BGD

9, 507-526, 2012

\section{Seasonal and latitudinal patterns of pelagic community metabolism}

S. Agusti

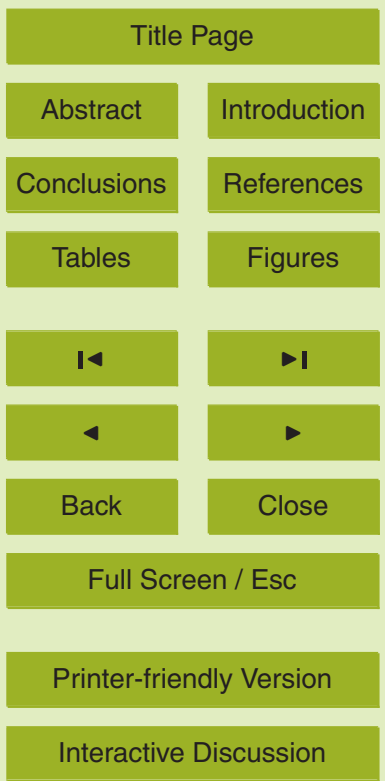


production and the consumption of organic carbon by the community by respiration. When production exceeds respiration, the net metabolism of the system is considered to be net autotrophic, contrary to the net heterotrophic metabolism that characterize a system where consumption exceeds production. The net metabolism of a system 5 is an important descriptor of the role of the biological processes in the carbon flow (Smith and Hollibaugh, 1993; Duarte and Agustí, 1998; Williams, 1998). Besides its importance, our knowledge on the net metabolism of the open ocean is remarkably small especially when compared with the accumulation of data on other parameters, as primary production, a single component of the pelagic metabolism (e.g. Duarte and 10 Regaudie de Gioux, 2009; Williams and del Giorgio, 2005; del Giorgio and Duarte, 2002). This paucity is even larger for the open oligotrophic ocean (del Giorgio and Duarte, 2002; Duarte and Regaudie de Gioux, 2009), for which we have in general less information.

Consumption should exceed respiration in unproductive areas of the ocean (Agustí 15 and Duarte; 1998; Agustí et al., 2004; Duarte et al., 2001; Williams and Robinson 2005; Duarte and Regaudieu de Gioux, 2009) but geographical and temporal variability of physical, chemical, and biological processes should generate different regional or seasonal variability in the net pelagic metabolism of the open ocean (e.g. Serret et al., 2002). Variability in the net metabolism of plankton generated by mesoscale processes has been identified in the oligotrophic North Atlantic (Gonzalez et al., 2001; MouriñoCarballido and McGillicuddy 2006). For coastal waters there are reports describing patterns at the temporal scale (e.g. Duarte et al., 2004; Gonzalez et al., 2008); however, temporal variability of oceanic pelagic net metabolism is still poorly explored and we lack description of the patterns of its variability in the oceanic areas (e.g. Gonzalez et al., 2002).

The goal of this study is to analyze the spatial and temporal variability on the metabolic balance of the pelagic communities of the Atlantic Ocean by quantifying the net community production and the community respiration at the surface ocean in a series of oceanographic cruises (LATITUDE cruises) that crossed the Atlantic Ocean
BGD

$9,507-526,2012$

\section{Seasonal and latitudinal patterns of pelagic community metabolism}

S. Agusti

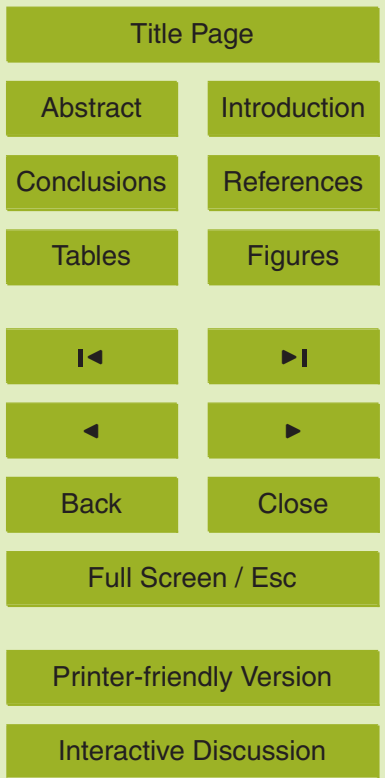


from the North Alantic (from the Canary Islands) to the South Atlantic (to the latitude of Buenos Aires or Montevideo). The measurements were performed on 4 cruises: two of then (LATITUDE-1 and LATITUDE-4) were conducted in March-April in years 1995 and 2000, respectively; and the other two (LATITUDE-2 and LATITUDE-3) were performed 5 in October-November, in years 1995 and 1999, respectively. The sampling stations were located within the same meridional regions for the four cruises, thus helping the analysis of the temporal variability in the data by reducing inter-cruise spatial variability. The present study provides new data from both North and South Atlantic subtropical Gyres, contributing to increasing our understanding of the biological metabolism in the 10 low productive areas of the ocean.

\section{Methods}

The study was performed during the cruises LATITUDE-1, 2, 3 and 4 across the Atlantic Ocean (Fig. 1). The LATITUDE-cruises comprised the sampling along transects from/to the South Atlantic, at latitudes of Uruguay-South Brazil, to/from the North At15 lantic close to the Canary Archipelago area. LATITUDE-1 ran from March to April 1995, LATITUDE-2 from October to November 1995, and LATITUDE-3 and 4 were made during November 1999 and March-April 2000, respectively. LATITUDE-2 included the sampling across the NW African upwelling in the most north eastern area visited (Fig. 1). Sampling stations followed the $29^{\circ} \mathrm{W}$ Meridian from $20^{\circ} \mathrm{S}$ to $30^{\circ} \mathrm{N}$ 20 during LATITUDE-1 (Fig. 1).

Seawater was sampled using Niskin bottles attached to a CTD-Rossette system. Subsamples of $250 \mathrm{ml}$ were filtered through Whatman GF/F filters for fluorometric analysis of chlorophyll-a concentration as described in Agustí and Duarte (1999). Surface water $(5 \mathrm{~m})$ was gently siphoned into narrow mouth $125 \mathrm{ml}$ replicated winkler bottles bottles) and community respiration (dark bottles), with 6-8 replicates each, depending on the station. Samples from LATITUDE-2, 3 and 4 were incubated for $24 \mathrm{~h}$ on deck, receiving screened (50\% reduction by a neutral net) natural light and submerged in

BGD

$9,507-526,2012$

\section{Seasonal and latitudinal patterns of pelagic community metabolism}

S. Agusti

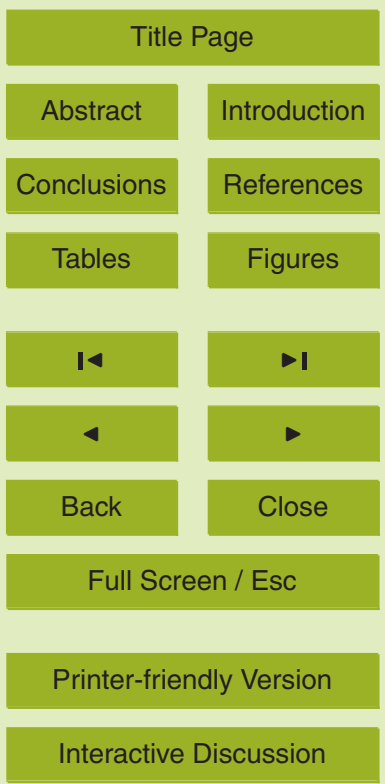


a large incubator (i.e. $1000 \mathrm{~L}$ ) refrigerated with running surface seawater. Samples from LATITUDE-I were placed in an incubator and maintained for $21-24 \mathrm{~h}$ at surface seawater temperature illuminated with artificial light $\left(500 \mu \mathrm{mol}\right.$ photons $\left.\mathrm{m}^{-2} \mathrm{~s}^{-1}\right)$.

Dissolved oxygen concentration was measured using high-precision Winkler titration 5 after Carrit \& Carpenter (1966), using a Mettler-DL21 Autotritator for the potentiometric (redox electrode) end-point detection (Oudot et al., 1988). Respiration rates were calculated from the difference in oxygen concentration between initial and "dark" bottles, and net community production was calculated from the difference in oxygen concentration between "light" bottles and the initial oxygen concentration. Gross primary 10 production was calculated as the sum of community respiration rates and net community production. In LATITUDE-1 samples were incubated under continuous light, and hourly net community production measured was converted to daily ( $24 \mathrm{~h})$ estimates by considering the length of the day and night periods for each sampling event.

\section{Results}

Values of net community production (NCP), community respiration $(\mathrm{R})$ and gross primary production (GPP) observed for the surface of the Atlantic Ocean were generally low, although the variability found was high (Table 1). Community respiration values ranged from 0.12 to $7.33 \mu \mathrm{molO}_{2} \mathrm{I}^{-1} \mathrm{~d}^{-1}$ and NCP varied from -6.87 to $53.65 \mu \mathrm{mol} \mathrm{O}_{2} \mathrm{I}^{-1} \mathrm{~d}^{-1}$. Values of GPP at the surface of the central Atlantic Ocean ranged from 0.03 to $3.91 \mu \mathrm{molO}_{2} \mathrm{I}^{-1} \mathrm{~d}^{-1}$ (Table 1). NCP values were mostly net heterotrophic along the study, as indicated by the high percentage of negative values observed $(86 \%)$ indicative of a higher consumption over production in the pelagic community of the surface of the Atlantic Ocean. NCP was negatively and strongly related to com10 munity respiration ( $\mathrm{NCP}=-0.89 \times \mathrm{R}+0.71, R^{2}=0.72, P<0.0001$, Fig. 2), but no relationship was found with other variables as chlorophyll-a concentration and GPP. GPP and $R$ were not related $\left(R^{2}=0.059\right)$. The ratio between GPP and $R(P / R$ ratio) was lower than 1 in $83 \%$ of the samples, indicative of a dominance of net

\section{BGD}

9, 507-526, 2012

\section{Seasonal and latitudinal patterns of pelagic community metabolism}

S. Agusti

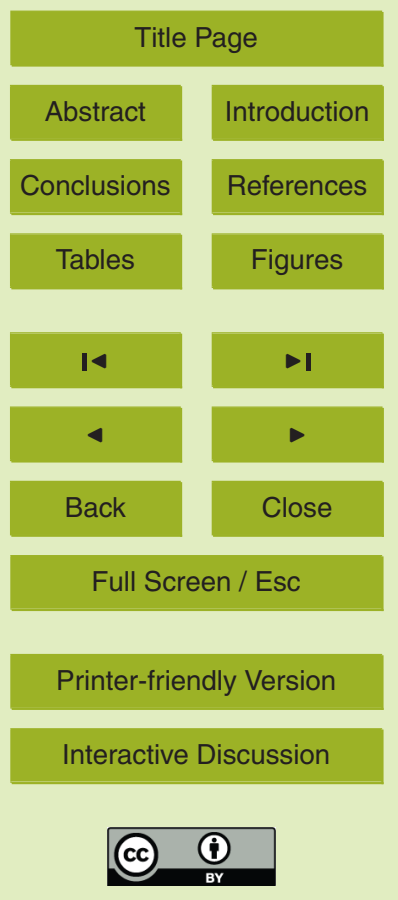


heterotrophic metabolism in the waters examined. $P / R$ was positively correlated with 15 GPP $\left(R^{2}=0.51, \log P / R=-0.188+1.14 \log\right.$ GPP, $P<0.0001$, model II regression $)$.

GPP varied with the latitude, showing increased values at the tropical zone between $10-20^{\circ}$ in both hemispheres (Fig. 3), decreasing with increasing latitude at the temperate area and decreasing again at the equatorial zone (Fig. 3). This pattern was also observed in the distribution of data from individual cruises (Fig. 3). The variability of GPP with latitude differed from that observed for chlorophyll-a (Fig. 4), which showed lower values at the South Atlantic, with the minimum values around $10^{\circ} \mathrm{S}$ among the transects; and increasing at the North Atlantic, with maximum chlorophyll-a values around the area influenced by the equatorial upwelling (Fig. 4). Data of community respiration and NCP did not show a pattern with latitude when all data were analyzed; however, they followed a latitudinal variation when the data were analyzed by season. At spring, $5 \mathrm{NCP}$ at the North Atlantic showed negative values at the tropical area, with most negative values found around $10^{\circ} \mathrm{N}$; NCP increased in the Southern Hemisphere in austral spring to reach positive values indicative of autotrophic net metabolism around $10^{\circ} \mathrm{S}$ (Fig. 5). This tendency was inverted in autumn, when negative values of NCP were observed at the South Atlantic, with the more negative values observed around $10^{\circ} \mathrm{S}$, although NCP values increased around $10^{\circ} \mathrm{N}$ during the boreal autumn until reaching positive, net autotrophic values (Fig. 4). The seasonal changes observed resulted in highly significant differences between spring and fall (in the Northern and Southern Hemispheres, Table 2) for averaged values of NCP and R, showing more heterotrophic waters and significantly higher respiration rates and higher temperature during the autumn (Table 2). There were no significant relationships between values of net community metabolism and community respiration with water temperature. For the surface waters of the Atlantic Ocean studied, Chl-a and GPP showed not seasonal differences between spring and fall (Table 2).
BGD

9, 507-526, 2012

\section{Seasonal and latitudinal patterns of pelagic community metabolism}

S. Agusti

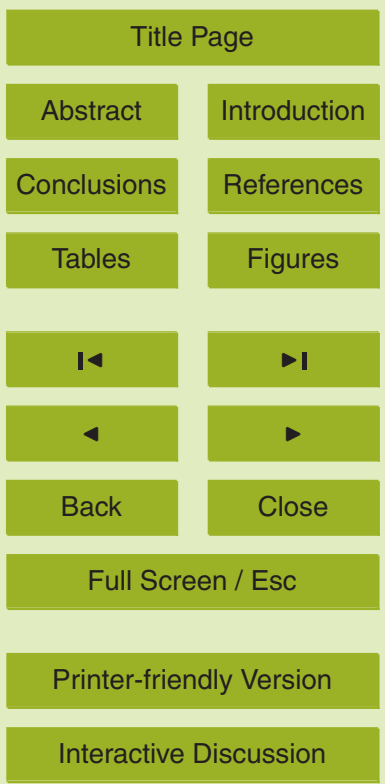




\section{Discussion}

20 The results presented here showed novel latitudinal and temporal patterns in the planktonic metabolism of the surface waters of the Atlantic Ocean. These patterns were identified despite the predominantly low values of productivity observed during the study. This low productivity was expected since the area included the sampling in the ultra oligotrophic waters of both North and South Atlantic subtropical gyres 25 (e.g. Duarte and Agustí, 1998; Williams, 1998; Duarte et al., 2001; Gonzalez et al., 2002; Serret et al., 2006). In $83 \%$ of the samples analyzed, community respiration exceeded gross primary production, indicating that the metabolism of the surface of the Atlantic Ocean was, predominantly, net heterotrophic. The gross production required to render the communities net autotrophic was $1,46 \mu \mathrm{molO}_{2} \mathrm{I}^{-1} \mathrm{~d}^{-1}$ (equivalent to $0,046 \mathrm{~g} \mathrm{O}_{2} \mathrm{~m}^{-3} \mathrm{~d}^{-1}$ ), which was very close to the threshold value calculated 5 by Duarte and Agustí (1998) for aquatic ecosystems, and the value reported recently by Duarte and Regaudie de Gioux (2009), for a larger data set for marine waters.

Moreover, the low production characterizing the Atlantic Ocean and the dominance of a net heterotrophic metabolism at the surface waters indicated clear patterns in the metabolic balance, with communities showing changes from net heterotrophic to 10 net autotrophic at the seasonal and latitudinal scales. The temporal patterns observed here at the surface waters has not been described before, since most studies analyzing the variability of the net metabolic balance in the Atlantic Ocean have focused on the variability across biogeographical regions and analyzed the integrated water column metabolism (e.g. Robinson et al., 2002; Gonzalez et al., 2002; Serret et al., 2002, 15 2006). Gonzalez et al. (2002) identified however the temporal variability in a year scale across the Atlantic, describing larger variability in the temperate areas of both $\mathrm{S}$ and $\mathrm{N}$ Atlantic, associated to its seasonality. Here, variability was also observed in the temperate waters sampled, as described in other studies (e.g. Gonzalez et al., 2002), but the variability in the intertropical boundaries was identified here because the study included inter-annual data, and a more detailed sampling spatial resolution than
BGD

$9,507-526,2012$

\section{Seasonal and latitudinal patterns of pelagic community metabolism}

S. Agusti

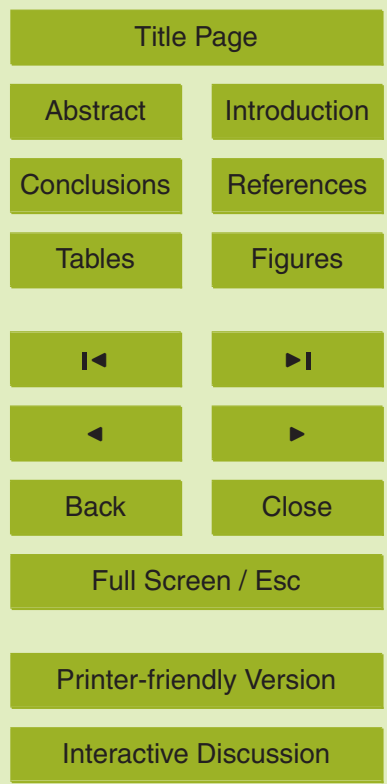


previous studies (e.g. Robinson et al., 2002; Serret et al., 2002, 2006; Gonzalez et al., 2002), as the effort was done at a single layer.

The larger variability in the metabolic balance was observed at the margins of the inter-tropical zone, probably associated to the boundaries of the subtropical Gyres 25 and its seasonal oscillation (e.g. Li and Philander, 1997; Chiang et al., 2002). At the North Atlantic, the major oscillation of the net metabolism was observed at around $10^{\circ}-$ $12^{\circ} \mathrm{N}$, with the pelagic metabolism reaching net autotrophic values in boreal autumn, but showing strong net heterotrophic values during the boreal spring. This temporal variability should be related to the seasonal cycle of the equatorial Atlantic area that showed the highest and lowest temperatures in March and September (Li and Philander, 1997). The boundaries between the Gyres and the equatorial area are driven by the complex system of currents of the equatorial zone, whose dynamics also change seasonally. In the North Atlantic, the North Equatorial Current extends from approx5 imately $16-12^{\circ} \mathrm{N}$ with a uniform flow towards the south and west (e.g. Richardson and Walsh, 1986; Peterson and Stramma, 1991; Hooke et al., 2000). Southernly, the Guinea dome province should extend from $12-8^{\circ} \mathrm{N}$, and represents a highly seasonal mid-ocean upwelling, showing the main period of upwelling between July and September (e.g. Aiken et al., 2000). This seasonality described for the North Atlantic equatorial 10 area was reflected in the net community metabolism measured here, which showed increased autotrophic metabolism during the boreal fall cruises, reflecting most probably the influence of the summer upwelling. A similar but opposite trend was observed at the South Atlantic where the net metabolism showed the highest negative values during the austral fall, but increased to reach a net autotrophic balance during the austral 15 spring (i.e. at the boreal fall). At the South Atlantic, the equatorial province extends from $16^{\circ} \mathrm{N}-15^{\circ} \mathrm{S}$ and is also highly dynamic influenced by the South Equatorial Current (SEC), which is strongest during the austral winter (e.g. Krauss, 1986; Peterson and Stramma, 1991). The southern branch of the westward flowing SEC is fed by the Benguela Current, which flows through a strong, biologically productive upwelling re20 gion, and advects cool waters to the tropics with high speeds during the austral winter

BGD

$9,507-526,2012$

\section{Seasonal and latitudinal patterns of pelagic community metabolism}

S. Agusti

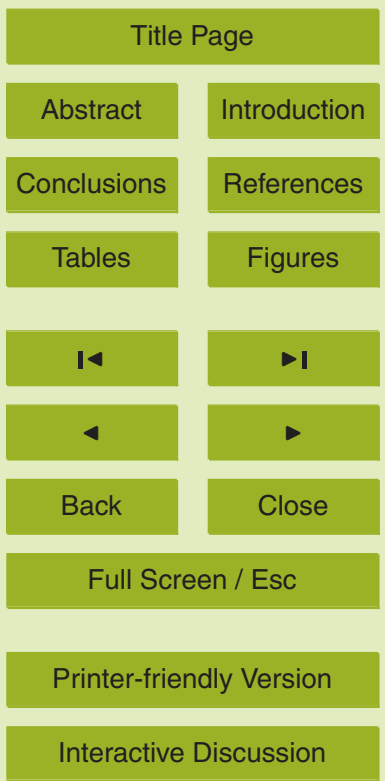


(Richardson and Walsh, 1986; Johns et al., 1998).

The seasonality and latitudinal variability found here for the net metabolism in the Atlantic surface was larger than that observed for chlorophyll-a concentration, that, despite displaying seasonal variability as well, always maintained higher values at the tropical North Atlantic as a result of being highly influenced by the guinea and equatorial upwelling systems (e.g. Aiken et al., 2002). Community respiration strongly explained the changes in NCP values in this study, indicating the importance of the heterotrophic metabolism in determining NCP. Heterotrophic organisms, such as zooplankton or bacteria, in the Atlantic Ocean are dependent on chlorophyll-a concentration but also on the variability of other processes. For example, both Chl-a and water temperature explained zooplankton egg production in the Atlantic Ocean, resulting in higher reproductive capacity at the equatorial area where both values increased (Calbet and Agustí, 1999). Low variability in Chl-a but high in zooplankton biomass 5 was described by Finenko et al. (2003) for the Atlantic inter-equatorial zone, showing seasonal changes in the Chl-a to zooplankton biomass ratio. The lower Chl-a to zooplankton biomass ratio in this area was observed for winter-spring due to higher zooplankton biomass during this period (Finenko et al., 2003), which is in accordance with higher net-heterotrophic balance found here in the March-April cruises. Hoppe et al. (2002) identified the heterotrophic component of pelagic communities (i.e. heterotrophic bacteria) as key for the prediction of the metabolic balance of the Atlantic Ocean, and identified changes in temperature to strongly influence bacteria (Hoppe et al., 2002). Water temperature, considered to exert strong control of community respiration (López-Urrutia et al., 2006), varied significantly between spring and fall in the oceanic pelagic metabolism, calculated that $P / R$ equals 1 at an average temperature of $23.5^{\circ} \mathrm{C}$. Surface Atlantic waters in spring were closer to the metabolic balance than during the fall, and showed a lower averaged temperature of $24.13 \pm 0.34$, close to the value calculated by Regaudie-de-Gioux (2010). This suggests that temperature is a proxy for the oceanographic and climatic changes influencing the metabolism of the
BGD

$9,507-526,2012$

\section{Seasonal and latitudinal patterns of pelagic community metabolism}

S. Agusti

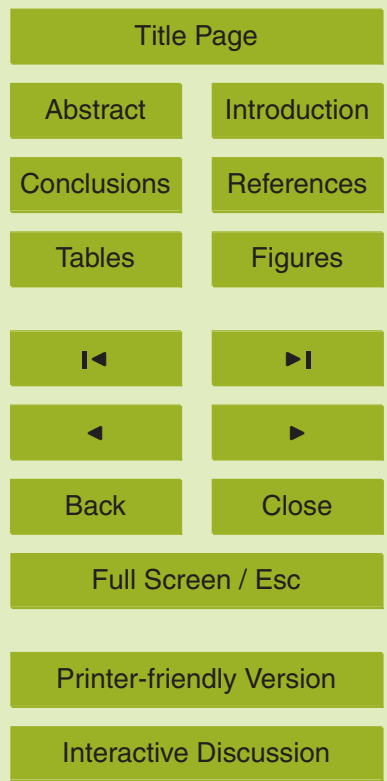


surface Atlantic Ocean. The results support the idea that understanding and predicting the net metabolic balance of the oceans would require a better knowledge of the oceanographic and climatic processes influencing the heterotrophic component of the plankton communities (Hoppe et al., 2002; Serret et al., 2006).

25 Acknowledgements. This is a contribution to the projects "LATITUD" and to the project "Expedition Malaspina-2010" CONSOLIDER project funded by the Spanish Ministry of Science and Innovation. The author is grateful to the Commanders, crews, and UTM technicians, of the Spanish Research Vessel BIO Hespérides for their professional assistance during the cruises, and to P. Satta, G. Carreras, and B. Casas, for their help with the sampling and analysis, and to M. González, for figures preparation.

\section{References}

Agustí, S. and Duarte, C. M.: Phytoplankton chlorophyll a distribution and water column stability in the central Atlantic Ocean, Oceanol. Acta, 22, 193-203, 1999.

Agustí, S., Satta, M. P., and Mura, M. P.: Summer community respiration and pelagic metabolism in upper surface Antarctic waters, Aquat. Microb. Ecol., 35, 197-205, 2004.

Aiken, J., Rees, N., Hooker, S., Holligan, P., Bale, A., Robins, D., Moore, G. , Harris, R., and Pilgrin, D.: The Atlantic Meridional Transect: overview and synthesis of data, Progress 10 Oceanogr., 45, 257-312, 2000.

Calbet, A. and Agustí, S.: Latitudinal changes of copepod egg production rates in Atlantic waters: temperature and food availability as the main driving factors, Mar. Ecol. Prog. Ser., 181, 155-162, 1999.

Carrit, D. E. and Carpenter, J. H.: Comparison and evaluation of currently employed modifications of the Winkler method for determining dissolved oxygen in sea-water, J. Mar. Res., 24, 286-318, 1966.

Chiang, J. C. H., Kushnir, Y., and Giannini, A.: Deconstructing Atlantic Intertropical Convergence Zone variability: Influence of the local cross-equatorial sea surface temperature gradient and remote forcing from the easter equatorial Pacific., J. Geophys. Res., 107, 4004,
BGD

9, 507-526, 2012

\section{Seasonal and latitudinal patterns of pelagic community metabolism}

S. Agusti

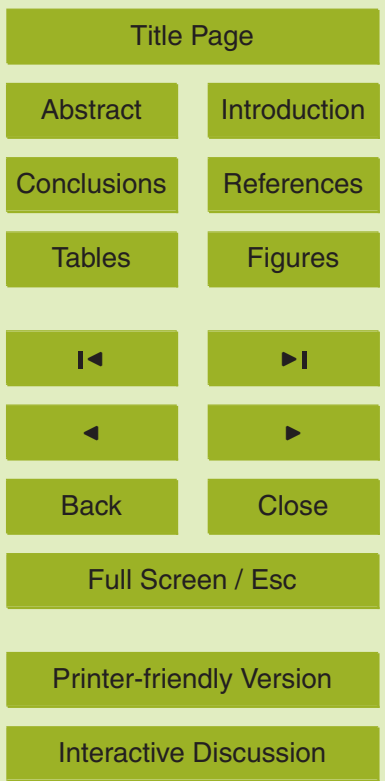


Del Giorgio, P. A. and Duarte, C. M: Respiration in the open Ocean, Nature, 420, 379-384, 2002.

Duarte, C. M. and Agustí, S.: The $\mathrm{CO}_{2}$ balance of unproductive aquatic ecosystems, Science, 281, 234-236, 1998.

25 Duarte, C. M. and Regaudie-de-Gioux, A.: Thresholds of gross primary production for the metabolic balance of marine planktonic communities, Limnol. Oceanogr., 54, 1015-1022, 2009.

Duarte, C. M., Agustí, S., Arístegui, J., Gonzalez, N., and Anadón, R. : Evidence for a heterotrophic subtropical northeast Atlantic, Limnol. Oceanogr., 46, 425-428, 2001.

Duarte, C. M., Agustí, S., and Vaqué, D.: Controls on planktonic metabolism in the Bay of Blanes, north-western Mediterranean littoral, Limnol. Oceanogr., 49, 2162-2170, 2004.

Finenko, Z. Z., Piontkovski, S. A., Williams, R., and Mishonov, A. V.: Variability of phytoplankton and mesozooplankton biomass in the subtropical and tropical Altantic Ocean, Mar. Ecol. Progr. Ser., 250, 125-144, 2003.

Gasol , J. M., Vázquez-Domínguez, E., Vaqué, D., Agustí, S., and Duarte, C. M.: Bacterial activity and diffusive nutrient supply in the oligotrophic Atlantic Ocean, Aqu. Micob. Ecol., 56, $1-12,2009$.

5 González, N., Anadón, R., Mouriño, B., Fernández, E., Sinha, B., Escanez, J., and de Armas, D.: The metabolic balance of the planktonic community in the north Atlantic Subtropical gyre: the role of mesoscale instabilities, Limnol. Oceanogr., 46, 946-952, 2001.

González, N., Anadón, R., and Marañón, E.: Large-scale variability of planktonic net community metabolism in the Atlantic Ocean: importance of temporal changes in oligotrophic subtropical

10 waters, Mar. Ecol. Prog. Ser,, 233, 21-30, 2002.

González, N., Gattuso, J. P., and Middelburg, J. J.: Oxygen production and carbon fixation in oligotrophic coastal bays and the relationship with gross and net primary production, Aquat. Microb. Ecol., 52, 119-130, 2008.

Hooker, S. B., Rees, N. W., and Aiken, J.: An objective methodology for identifying oceanic provinces, Progr. Oceanogr., 45, 313-338, 2000.

Hoppe, H.-G., Gocke, K., Koppe, R., and Begler, C.: Bacterial growth and primary production along a north-south transect of the Atlantic Ocean, Nature, 416, 168-171, 2002.

Johns, W. E., Lee, T. N., Beardsley, R. C., Candela, J., Limeburner, R., and Castro, B.: Annual Cycle and Variability of the North Brazil Current, J. Physic. Oceanogr., 28, 103-128, 1998.

20 Krauss, W.: The North Atlantic Current, J. of Geophys. Res., 91, 5061-5074, 1986.

BGD

$9,507-526,2012$

\section{Seasonal and latitudinal patterns of pelagic community metabolism}

S. Agusti

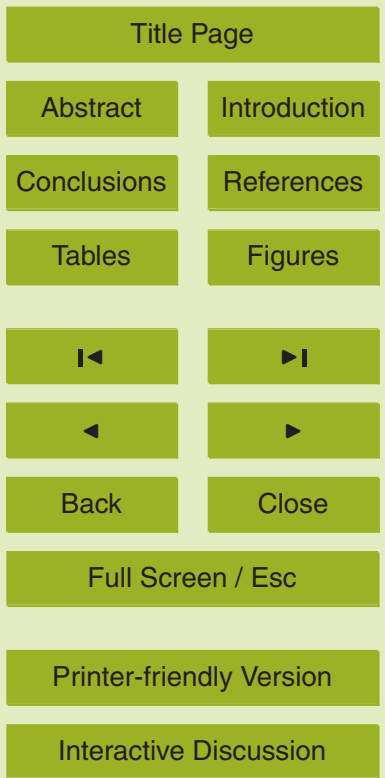


Li, T. and Philander, S. G. H.: On the Seasonal cycle of the Equatorial Atlantic Ocean, J. Climate, 10, 813-817, 1997.

López-Urrutia, Á., San Martin, E., Harris, R. P., and Irigoyen, W.: Scaling the metabolic balance of the oceans, Proc. Natl. Acad. Sci., 103, 8739-8744, 2006.

25 Mouriño-Carballido, B. and McGillicuddy, D. J. : Mesoscale variability in the metabolic balance of the Sargasso Sea, Limnol. Oceanogr., 51, 2675-2689, 2006.

Oudot, C., Gerard, R., Morin, P., and Gningue, I.: Precise Shipboard Determination of Dissolved-Oxygen (Winkler Procedure) for Productivity Studies with a Commercial System, Limnol. Oceanogr., 33, 146-150, 1988.

so Peterson, R. G. and Stramma, L.: Upper level circulation in the South Atlantic ocean, Progr. Oceanogr., 26, 1-73, 1991.

Regaudie-de-Gioux, A.: Patterns in Ocean metabolism: rates, balance and controls. PhD Thesis, Universitat de les lles Balears, Palma de Mallorca, 190 pp., 2010.

Richardson, P. L. and Walsh, D.: Mapping climatological seasonal variations of surface currents in the tropical Atlantic using ship drifts, J. Geophys. Res., 91, 10 537-10 550, 1986.

Robinson, C., Serret, P., Tilstone, G., Teira, E., Zubkov, M. V., Rees, A. P., and Woodward, E. M. S.: Plankton respiration in the Eastern Atlantic Ocean, Deep-Sea Res., 49, 787-813, 2002.

Serret, P., Fernández, E., and Robinson, C.: Biogeographic differences in the net ecosystem metabolism of the open ocean, Ecology, 83, 3225-3234, 2002.

Serret, P., Fernández, E., Robinson, C., Woodward, E. M. S., and Pérez, V.: Local production does not control the balance between plankton photosynthesis and respiration in the open Atlantic Ocean, Deep-Sea Res., 53, 1611-1628, 2006.

Smith, S. V. and Hollibaugh, J. T.: Coastal metabolism and the oceanic organic carbon balance, Rev. Geophys., 31, 75-93, 1993.

Williams, P. J. and Le, B.: The balance of plankton respiration and photosynthesis in the open oceans, Nature, 394, 55-57, 1998.

Williams P. J., Le, B., and del Giorgio, P. A.: Respiration in aquatic ecosystems: History and Background, in: Respiration in aquatic ecosystems, edited by: del Giorgio, P. A., Williams P. J., Le, B., Oxford University Press, 1-17, Oxford, 2005.

BGD

$9,507-526,2012$

\section{Seasonal and latitudinal patterns of pelagic community metabolism}

S. Agusti

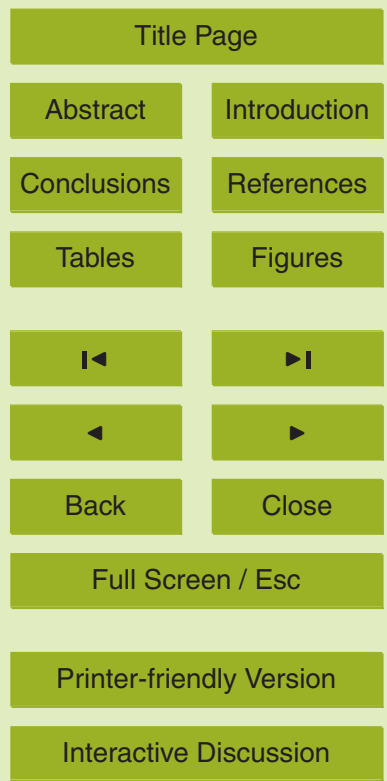




\section{BGD}

9, 507-526, 2012

\section{Seasonal and latitudinal patterns of pelagic community metabolism}

Table 1. Mean values ( \pm SE) of Net Community Production (NCP), Community Respiration (R) and Gross Primary Production (GPP) observed in surface waters of the South and North Atlantic in the different LATITUDE cruises.

\begin{tabular}{lcccc}
\hline & $\mathrm{N}$ & $\begin{array}{c}\mathrm{NCP} \\
\left(\mu \mathrm{mol} \mathrm{O} \mathrm{I}^{-1} \mathrm{~d}^{-1}\right)\end{array}$ & $\left.\begin{array}{c}\mathrm{R} \\
(\mu \mathrm{mol} \mathrm{O}\end{array} \mathrm{I}^{-1} \mathrm{~d}^{-1}\right)$ & $\begin{array}{c}\mathrm{GPP} \\
\left(\mu \mathrm{mol} \mathrm{O} \mathrm{I}^{-1} \mathrm{~d}^{-1}\right)\end{array}$ \\
\hline LATITUDE-1 (1995) & 34 & $-1.78 \pm 0.25$ & $2.28 \pm 0.25$ & $0.50 \pm 0.06$ \\
LATITUDE-2 (1995) & 10 & $-0.89 \pm 0.39$ & $2.09 \pm 0.31$ & $1.61 \pm 0.27$ \\
LATITUDE-3 (1999) & 13 & $0.27 \pm 0.40$ & $1.32 \pm 0.36$ & $1.59 \pm 0.28$ \\
LATITUDE-4 (2000) & 10 & $-1.96 \pm 0.68$ & $3.39 \pm 0.79$ & $1.42 \pm 0.39$ \\
\hline
\end{tabular}

S. Agusti

Title Page

Abstract Introduction

Conclusions References

Tables Figures

14

4

Back

Close

Full Screen / Esc

Printer-friendly Version

Interactive Discussion 


\section{BGD}

9, 507-526, 2012

\section{Seasonal and latitudinal patterns of pelagic community metabolism}

Table 2. Season averaged values ( \pm SE) of chlorophyll-a concentration (Chl-a), Gross Primary Production (GPP), surface water temperature (T), Net Community Production (NCP) and Community Respiration (R), for the four LATITUDE cruises. * Significant One Way Anova probability.

\begin{tabular}{lccc}
\hline & $\begin{array}{c}\text { Spring } \\
\text { (Boreal and Austral) }\end{array}$ & $\begin{array}{c}\text { Autumn } \\
\text { (Boreal and Austral) }\end{array}$ & Probability \\
\hline $\mathrm{Chl}-\mathrm{a}\left(\mu \mathrm{g} \mathrm{I}^{-1}\right)$ & $0.116 \pm 0.015$ & $0.127 \pm 0.018$ & 0.64 \\
$\mathrm{GPP}\left(\left.\mu \mathrm{mol} \mathrm{O}{ }_{2}\right|^{-1} \mathrm{~d}^{-1}\right)$ & $1.04 \pm 0.14$ & $0.91 \pm 0.17$ & 0.58 \\
$\mathrm{~T}\left({ }^{\circ} \mathrm{C}\right)$ & $24.13 \pm 0.34$ & $27.26 \pm 0.36$ & $<0.0001 *$ \\
$\mathrm{NCP}\left(\left.\mu \mathrm{mol} \mathrm{O}_{2}\right|^{-1} \mathrm{~d}^{-1}\right)$ & $-0.56 \pm 0.26$ & $-2.14 \pm 0.30$ & $<0.0002 *$ \\
$\mathrm{R}\left(\mu \mathrm{mol}_{2} \mathrm{I}^{-1} \mathrm{~d}^{-1}\right)$ & $1.70 \pm 0.24$ & $3.19 \pm 0.29$ & $<0.0003 *$ \\
\hline
\end{tabular}

S. Agusti

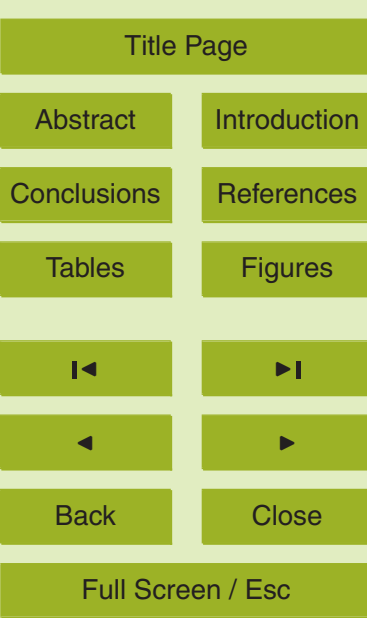

Printer-friendly Version

Interactive Discussion 


\section{BGD}

9, 507-526, 2012

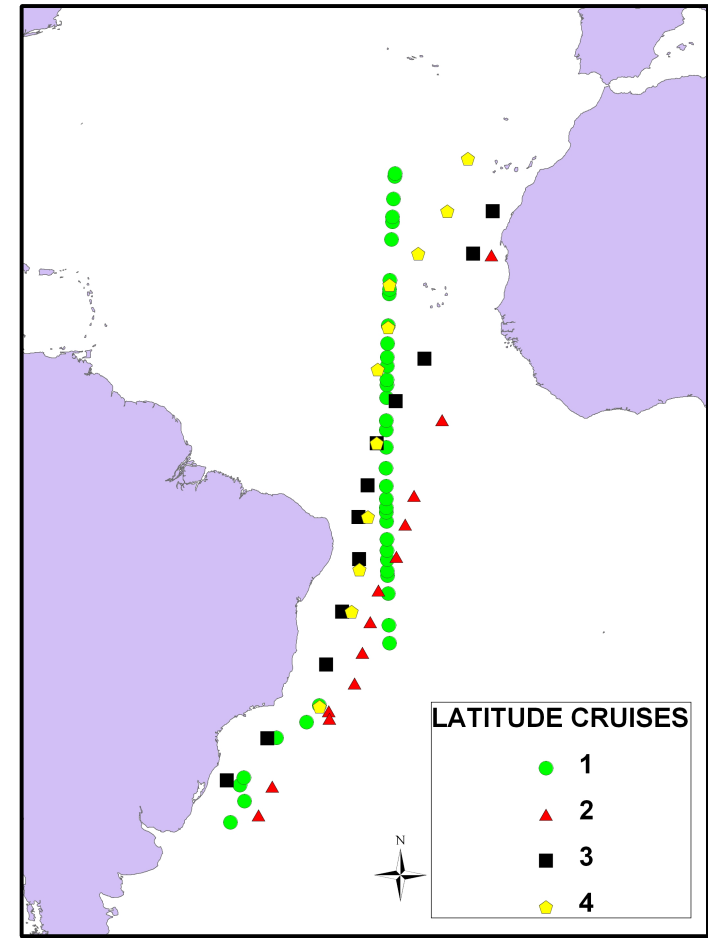

Seasonal and latitudinal patterns of pelagic community metabolism

S. Agusti

Title Page

\section{Abstract}

Conclusions

Tables

14

4

Back

Full Screen / Esc

Printer-friendly Version

Interactive Discussion 


\section{BGD}

9, 507-526, 2012
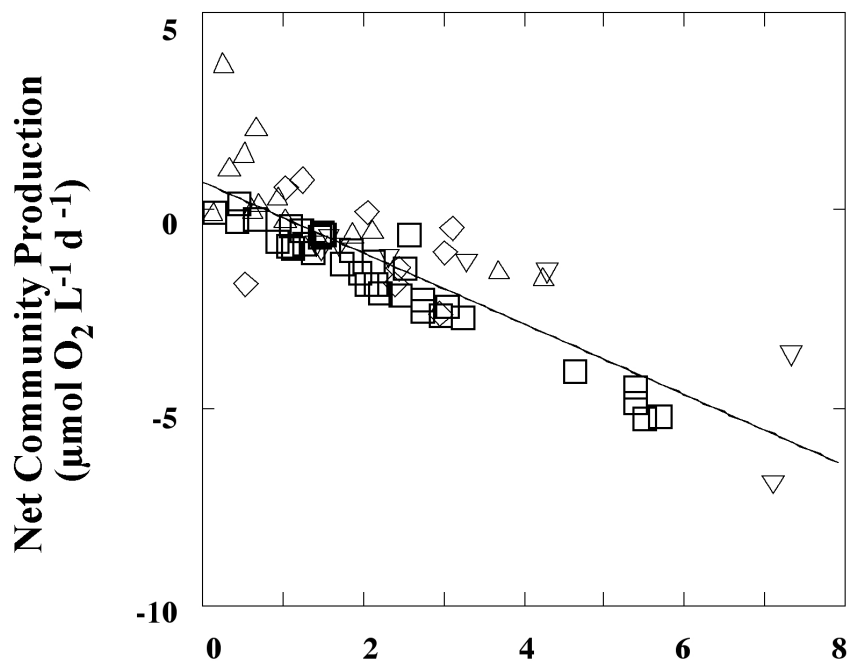

\section{Seasonal and latitudinal patterns of pelagic community metabolism}

S. Agusti

\section{Community Respiration $\left(\mu \mathrm{mol} \mathrm{O} \mathrm{L}^{-1} \mathrm{~d}^{-1}\right)$}

Fig. 2. The relationship between Net Community Production (NCP) and Community Respiration $(R)$ for the surface pelagic communities sampled during the study. The solid line represents the fitted regression equation. The symbols corresponded to the 4 cruises: Squares: LATITUD1, Diamonds: LATITUD-2, Triangles: LATITUD-3, and inverted Triangles: LATITUD-4.

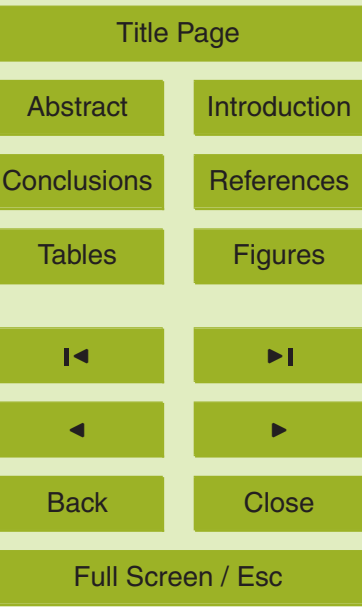

Printer-friendly Version

Interactive Discussion 


\section{BGD}

9, 507-526, 2012

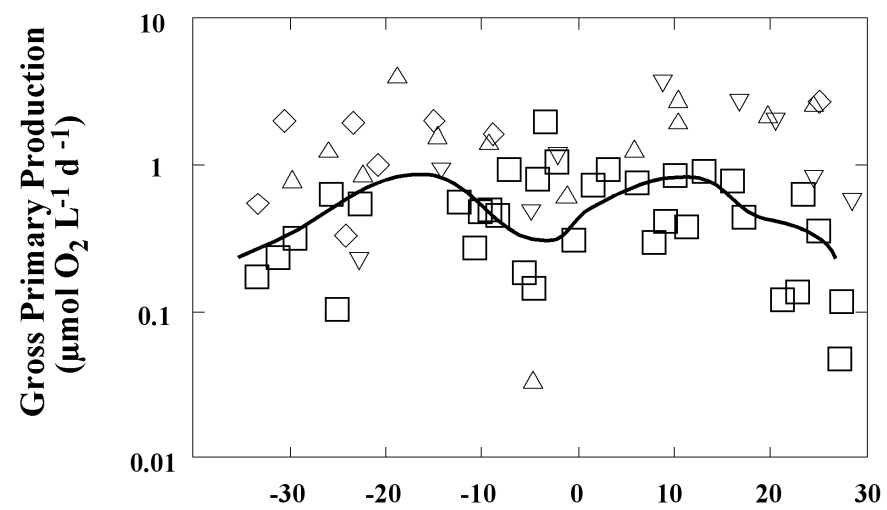

\section{Seasonal and latitudinal patterns of pelagic community metabolism}

S. Agusti

\section{Latitude (+N, -S)}

Fig. 3. Distribution of surface Gross Primary Production (GPP) with the latitude. The line represents the Lowest fit model. Symbols are as described in Fig. 2.

Title Page

\section{Abstract}

Introduction

Conclusions

References

Tables

Figures

14

Back

Full Screen / Esc

Printer-friendly Version

Interactive Discussion 


\section{BGD}

9, 507-526, 2012

\section{Seasonal and latitudinal patterns of pelagic community metabolism}

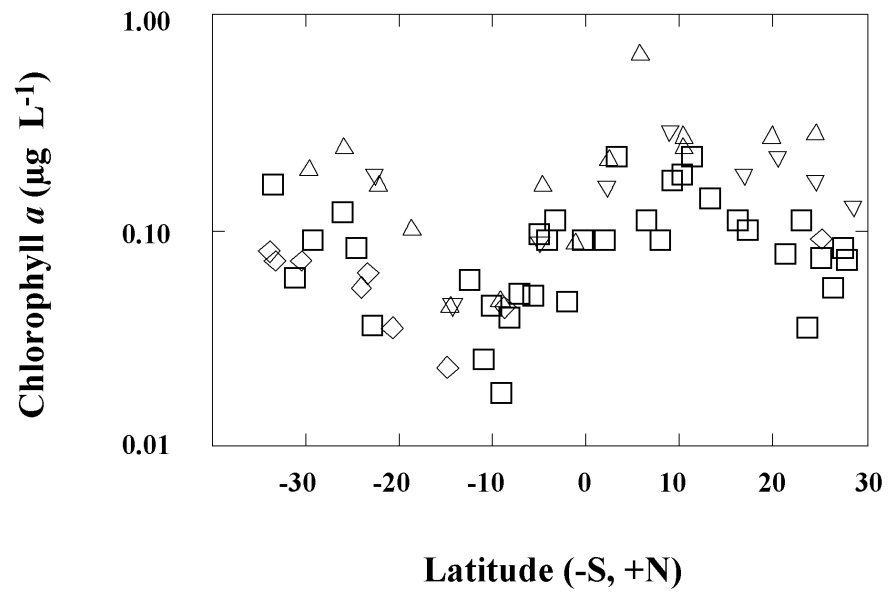

Fig. 4. Distribution of chlorophyll-a concentration with latitude, found at the surface of the Atlantic Ocean during the four LATITUDE cruises. Symbols are as described in Fig. 2.
S. Agusti

Title Page

Abstract

Introduction

Conclusions

References

Tables

Figures

14

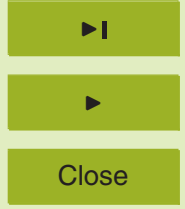

Back

Full Screen / Esc

Printer-friendly Version

Interactive Discussion 


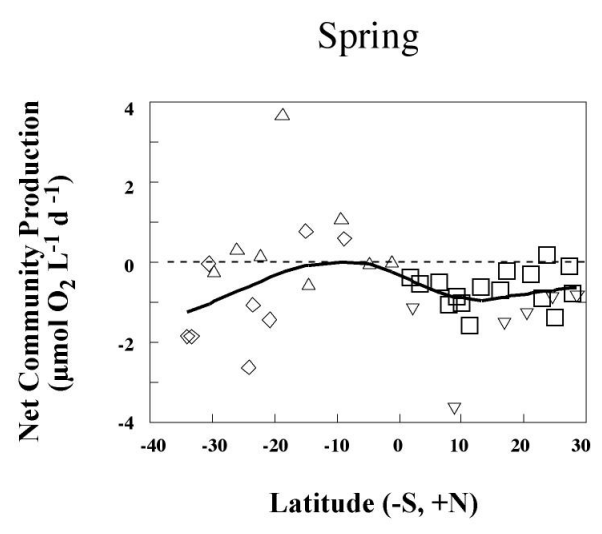

\section{BGD}

$9,507-526,2012$

\section{Seasonal and latitudinal patterns of pelagic community metabolism}

S. Agusti

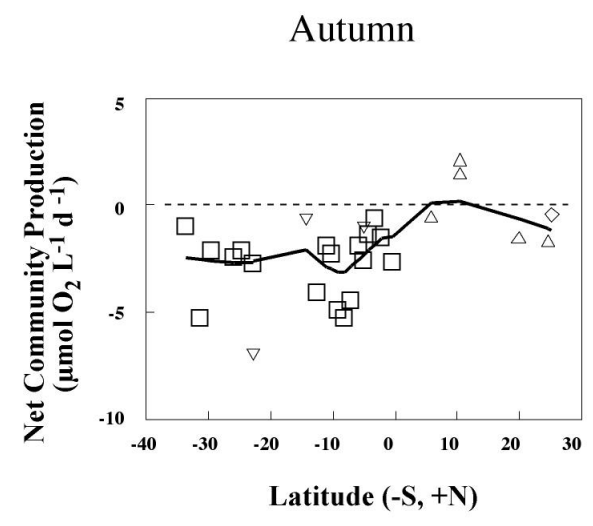

Title Page

Abstract

Conclusions

\section{Tables}

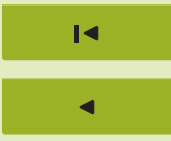

Back
Introduction

References

Figures

- I

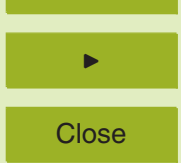

Full Screen / Esc

Printer-friendly Version

Fig. 5. Distribution with the latitude of surface Net Community Production (NCP) measured in the stations sampled during boreal and austral spring, and during boreal and austral autumn. The lines represent the lowest fitted models. Symbols are as described in Fig. 2. 